\title{
USING SENTINEL IMAGE DATA AND PLOT SURVEY FOR THE ASSESSMENT OF BIOMASS AND CARBON STOCK IN COASTAL FORESTS OF THAI BINH PROVINCE, VIETNAM
}

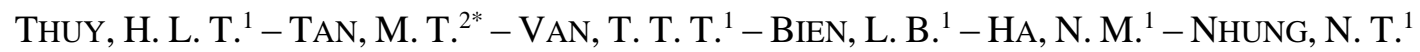 \\ ${ }^{1}$ Institute of Geography, Vietnam Academy of Science and Technology, 18 Hoang Quoc Viet \\ str., Cau Giay dist., Hanoi 100000, Vietnam \\ ${ }^{2}$ Institute of Geological Sciences, Vietnam Academy of Science and Technology, 84 Chua Lang \\ str., Dong Da dist., Hanoi 100000, Vietnam \\ *Corresponding author \\ e-mail: maithanhtan@igsvn.vast.vn; phone: +84-912-342-465
}

(Received $4^{\text {th }}$ Mar 2020; accepted $10^{\text {th }}$ Jul 2020)

\begin{abstract}
Quantitative evaluation of biomass and carbon stored in coastal forests of Thai Binh province (Vietnam) does not only contribute to coast protection, but is also required for emphasizing the forest's importance in local socio-economic development when participating in the carbon market. This estimation is primarily based on field data (diameter at breast height, height and quantity of tree in 14 surveyed plots), anatomical data (above ground biomass, total biomass and carbon content of 31 sampled trees) and an NDVI map calculated from Sentinel imagery. Mathematical models are used for expressing the relationships: above ground biomass vs. diameter at breast height, height; biomass vs. above-ground biomass; biomass vs. carbon; and aboveground biomass vs. NDVI. The results show the same behavior of above ground biomass, total biomass and carbon stock, they increase with the growth of tree. The exponential model is acceptable for correlating above ground biomass and NDVI, showing higher values in long planted areas and the lower ones in newly formed lands with recently planted mangroves. Biomass and carbon stock in the study area have average productivities of 38.8 tha and 19.4 t/ha, respectively. Overall estimations are ca. 292 kilotons of biomass and ca. 146 kilotons of carbon, roughly valuated of US $\$ 5.9$ million.
\end{abstract}

Keywords: $A G B, N D V I$, mangrove, remote sensing data, $\mathrm{CO}_{2}$ valuation, Vietnam

\section{Introduction}

Forests play a critical role in the Earth's climate system, in a number of different ways. Most importantly concerning global climate change, they capture $\mathrm{CO}_{2}$ from the atmosphere, convert it into living biomass (stems, roots, branches and leaves) through photosynthesis and store large amounts of carbon in forest soils, absorbed through leaf litter, wood debris and roots (Brack, 2019). The estimates of carbon stored in forest ecosystems in the world vary significantly. In 2000, the Intergovernmental Panel on Climate Change estimated the total amount to be 1,100 gigatons (Gt) (Watson et al., 2000), which is 1.3 times greater than the carbon stored in fossil fuels (estimated at $800 \mathrm{Gt}$ ) and much larger than carbon released into the atmosphere from human activity since 1870 (about $600 \mathrm{Gt}$ ) (Federici et al., 2018). FAO (2010) yielded lower value of about $652 \mathrm{Gt}$, including 44\%, 5\%,6\% and $45 \%$ in live biomass, dry biomass, garbage and forest soils respectively. Therefore, a large amount of $\mathrm{CO}_{2}$ will be released into the atmosphere from global deforestation. At the United Nations Climate Change Conference in Indonesia in December 2007, 187 member countries signed the Bali Agreement which outlined the program "Reducing Emissions from Deforestation and Forest Degradation" (REDD), with the aim to limit the destruction of tropical forests. Many countries will meet some of their emission reduction targets through the purchase 
of carbon credits of developing countries made available by absorption of $\mathrm{CO}_{2}$ by forests (United Nations Framework Convention on Climate Change - UNFCCC, 2007). So far, the carbon trading market has been divided into two types: the regulatory compliance and the voluntary markets. The regulatory compliance is the market in which carbon trading is based on the commitment of states in the UNFCCC to achieve the goal of reducing greenhouse gases. It is regulated by mandatory, mainly for Clean Development Mechanism (CDM) or Joint Implementation (JI) projects. The voluntary carbon market, outside the Kyoto Protocol framework, is based on bilateral or multilateral cooperation agreements between organizations, companies or countries. Thus, the problem posed here is to quantify the amount of $\mathrm{CO}_{2}$ stored by forest ecosystems in developing countries, including Vietnam. This work, first of all, requires identifying the biomass and carbon accumulated in these forests.

Forest biomass could be estimated by allometric functions relating biomass and dimensions of tree or its components such as Diameter at Breast Height (DBH), tree height $(\mathrm{H})$, trunk circumference, branches, roots, leaves, etc. (Clough and Scott, 1989; Comley and McGuinness, 2005; Basuki et al., 2009; Chave et al., 2014; Bao et al., 2016; Kebede and Soromessa, 2018). The $\mathrm{CO}_{2}$ absorption of forest ecosystems is generally determined by direct measurement of physiological processes controlling carbon balance (Botkin et al., 1970; Woodwell, 1970), analyzing eddy correlation for quantifying net ecosystem exchanges of $\mathrm{CO}_{2}$ (Wofsy et al., 1993), mathematical functions presenting the relationship between biomass, carbon stock and tree dimensions (Grier et al., 1989; Hunter et al., 2013; Ostadhashemi et al., 2014). Remote sensing data, including optical imagery (aerial photography, multispectral, and hyperspectral), Synthetic Aperture Radar (SAR) and Light Detection And Ranging (LiDAR) combined with field measurements, allometric equations, supported by GIS techniques are also used for estimating spatiotemporal variation of biomass and carbon stock in vegetation (Patenaude et al., 2004; Myeong et al., 2006; Jeyanny et al., 2011; Santoro and Cartus, 2018; Hirata et al., 2018; Pham et al., 2019). For the optical imagery, these estimations are usually based on regression models correlating Above Ground Biomass (AGB) and vegetation indices such as Normalized Difference Vegetation Index (NDVI), Green NDVI, Soil Adjusted Vegetation Index, Simple ratio, Red-edge simple ratio (Baloloy et al., 2018; Punalekar et al., 2018).

In Vietnam, biomass and forest productivity have also been studied for specific populations such as Rhizophora (Tri, 1986; Tan, 2001), Pinus kesiya (Phuc, 1996), Acacia auriculiformis (Thong, 1998), increased and diversified since the adoption of CDM (Lung and Van, 2004; Phuong, 2006; Hai et al., 2009; Trieu, 2010). Carbon stored in forest is also estimated and valuated (Ty, 2004; Nam, 2009; Tin and Loi, 2015). Recently remote sensing is applied for estimating biomass and carbon stock in mangrove (Vu et al., 2014; Pham and Yoshino, 2017; Quang and Hoa, 2018; Luong et al., 2019). For carbon trade within framework of Kyoto Protocol, there are numerous limitations impeding investments in Vietnam such as: inadequacies in approval process, lack of openness and transparency in mechanisms of financial allocation, etc. Vietnam currently has several projects towards carbon market (Lung and Van, 2004; Ty, 2004). In general, most of the studies focused on forest ecosystems in hilly and mountainous areas or mangroves in the coastal plain of southern Vietnam.

This study to evaluate the biomass and carbon stocks in coastal forests of Thai Binh province, belonging to the Red River Delta, not only fills up the lacking area but also contributes to the protection and development of these ecosystems, orienting to 
participate into the carbon market, increasing the importance of coastal forest in local socio-economic development, thereby raising awareness of mangrove protection in the strategy dealing with climate change, simultaneously contributes to biodiversity conservation for the Red River Delta Biosphere Reserve.

\section{Materials and methods}

\section{Study area}

The coastal area of Thai Binh Province, located in Thai Thuy and Tien Hai districts (Figure 1.), is considered as one of the areas rich in biodiversity and strongly affected by climate change. Its population is estimated approximately 458,700 people with a density of 917 inhabitants $/ \mathrm{km}^{2}$ (Thai Binh Statistical Office, 2016).

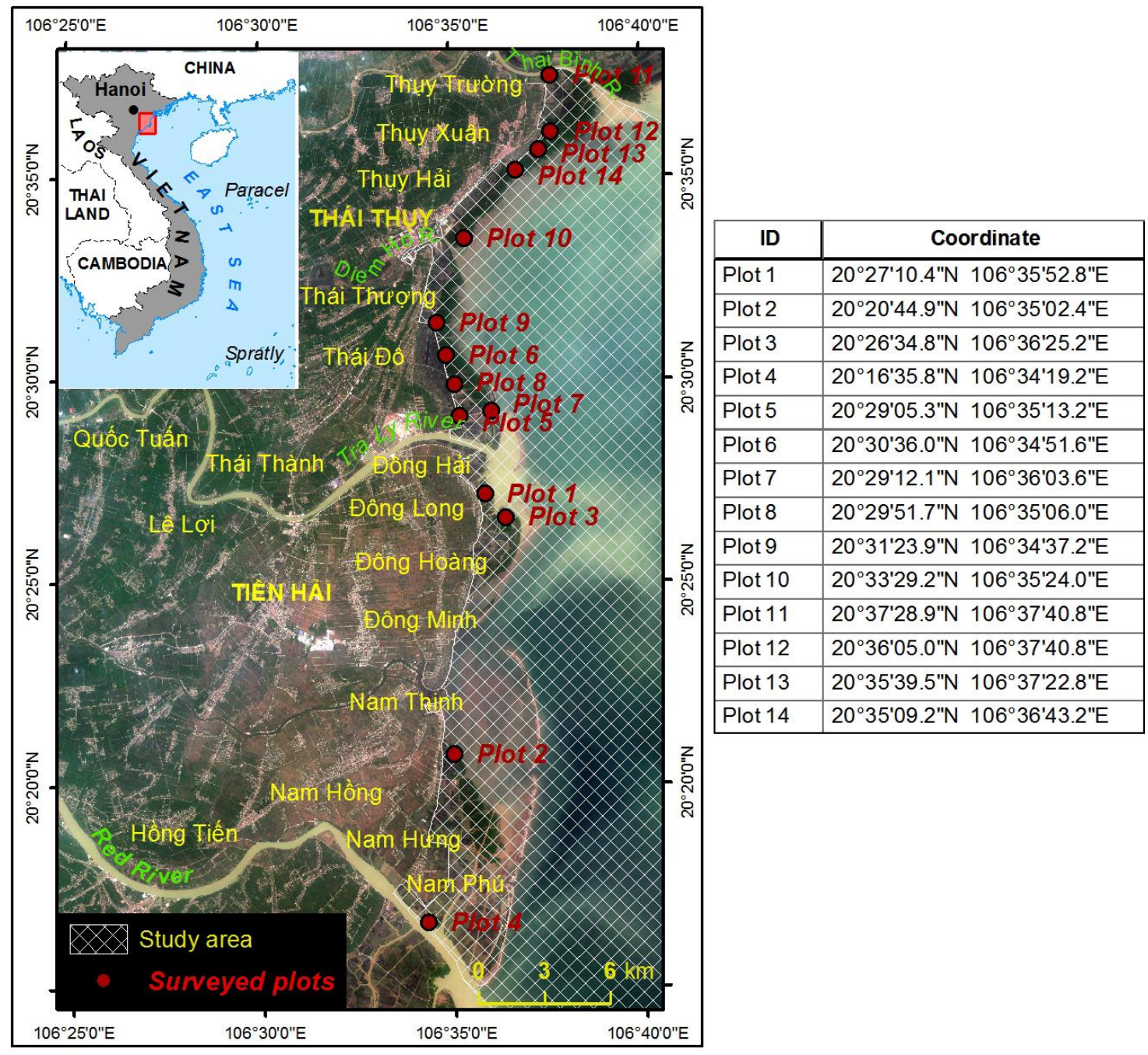

Figure 1. Study area and surveyed plots (Image: Sentinel-2A dated 10 Aug 2015)

This area is in tropical monsoon climate with annual average temperature about $22-24^{\circ} \mathrm{C}$, hottest in July (averagely $29.1^{\circ} \mathrm{C}$ ) and coldest in January (averagely $16.7^{\circ} \mathrm{C}$ ). The precipitation of $1,658 \mathrm{~mm} /$ year unevenly distributes among the months of the year. 
The rainy season, from May to September, makes up $70-80 \%$ of annual total. The rest time, from October to April, the monthly rainfall is usually below $100 \mathrm{~mm}$, resulting in water shortage. From May to November, especially in August, the area is hit by typhoons and tropical depressions, coming from the South China Sea with an average frequency of 2.1 times/year (Van et al., 2017).

Four major rivers, namely Thai Binh, Diem Ho, Tra Ly and Red rivers (Figure 1.), flowing through the study area to the sea, have complicated hydrological regime due to the influence of both Red and Thai Binh river systems. In general, there are two distinct seasons: the flood season, from June to October, accounts for $75-80 \%$ of the total annual flow; the dry, from November to May, makes up $20-25 \%$ of the total (Anh, 2016).

The wave regime, controlled by prevailing wind, has the directions: northeast in offshore area and northeast, east or southeast in coastal area for the winter; south in offshore area and southeast or south in coastal area for the summer. On the coast, winter waves can reach $0.4-0.9 \mathrm{~m}$ height in average and $3.0 \mathrm{~m}$ maximum; the summer waves are 0.7 to $1.2 \mathrm{~m}$ of average height and $6 \mathrm{~m}$ highest. Influenced by storms and tropical cyclones, the large waves in winter are more frequent than in summer. The diurnal tide with high amplitude in relief of gentle slope creates considerably large tidal flats with a width of $4-5 \mathrm{~km}$, even $7-8 \mathrm{~km}$ in Thai Binh estuary, favoring mangrove development for the study area (Anh, 2016).

Developed on Holocene unconsolidated sands, silts and clays, the relief of study area is relatively flat and low. The river-sea interaction produces the following landforms: river channels and floodplains, delta plains, ancient sandy dunes, high and low tidal flats, mouth bars. Among them, high and low tidal flats are the terrain suitable for mangrove development. Statistically, there are 13 soil types of sandy, saline, acid sulfate and alluvial groups in the area. Among them, the high, medium and low saline and tidal flat soils, related to mangrove forest, occupy 22,058.47 ha accounting for $37.23 \%$ of the total natural area of Tien Hai and Thai Thuy districts (Anh, 2016).

The total coastal forest of Thai Binh province occupies 3,899.1 ha, including 3,709.1 ha $(95 \%)$ of mangroves, in 10 communes and towns of the two districts Thai Thuy and Tien Hai (Thai Binh Department of Agriculture and Rural Development - TBDARD, 2016). Mangroves are mainly pure or mixed planted forests with following species in majority Sonneratia caseolaris, Kandelia obovata, Aegiceras corniculatum, Bruguiera gymnorohiza, Avicennia marina. Communities of Avicennia marina and Kandelia obovataare commonly distributed in the outermost area with high salinity and deep water. Sonneratia caseolaris, Kandelia obovata, and Aegiceras corniculatum are situated in moderately submerged area. The community with dominance of Sonneratia caseolaris and underbrush Acanthus ilicifoliusis mainly found in the estuarine area (Thuy et al., 2016). In Thai Thuy district, there are more than 2000 hectares of mangroves concentrated in 5 communes: Thuy Truong, Thuy Xuan, Thuy Hai, Thai Phuong and Thai Do. An inventory in Thuy Truong lists 38 plant families with 111 species in which 12 species are true mangrove sand 30 others are mangrove associates (Cuc and Tan, 2004). In Tien Hai district, mangroves are distributed mainly in five communes: Nam Thinh, Nam Hung, Nam Phu, Dong Long and Dong Hoang, in which the first three belong to Tien Hai Wetland Nature Reserve occupying an area of 1450 ha. This Reserve has: 11 species of true mangroves with 1 fern and 10 angiosperms; and 37 species of mangrove associates with 17 monocotyledons and 20 dicotyledons (Tuan and Anh, 2008). Outside of the reserve such as in Dong Long, 
the flora has quite high diversity with 66 species of 33 families, whose 8 species are true mangroves and 19 others are mangrove associates (Tam, 2013). For whole coastal zone of Thai Binh, there are 14 species of true mangrove in the communities of natural forest, planted forest, aquaculture ponds and new-land pioneer as follows (Van et al., 2017):

- 1 fern: Acrostichum aureum L.;

- 12 dicotyledons: Acathus ebracteatus Vahl, Acathus ilicifolus L., Sensuvium portulacastrum L, Avicennia marina (Forsk) Veirh), Lumnitzera racemosa (Gaud.) Presl., Derris trifoliata (Benth) Barker, Excoecaria agallaocha L, Aegiceras corniculatum (L.) Blanco, Bruguiera gymnorohiza (L), Kandelia obovata Sheue Liu \& Yong, Rhizophora stylosa Griff.and Sonneratia caseolaris (L.) Engl.;

- 1 monocotyledon: Cyperus stoloniferus Retz.

\section{Methods}

Biomass and carbon evaluation for the study area is firstly based on field data (DBH, $\mathrm{H}$ and tree quantity in surveyed plots), anatomical data (AGB, total biomass and carbon content of sampled trees) and NDVI map calculated from Sentinel imagery. From the anatomical data, the mathematical models expressing AGB vs. DBH and $\mathrm{H}$, Biomass vs. AGB, Biomass vs. Carbon relationships are set up. The mean AGB in pixel $\left(100 \mathrm{~m}^{2}\right)$ and mean NDVI are determined for each surveyed plot, and then expressed in a mathematical model, enabling to map AGB from NDVI for the study area. The biomass map can be produced from AGB map by Biomass vs. AGB expression and then carbon stock from biomass by Biomass vs. Carbon expression.

\section{Field survey}

In the study area, 14 key plots with sizes of $100 \mathrm{~m}^{2}(10 \mathrm{~m} \times 10 \mathrm{~m}), 500 \mathrm{~m}^{2}$ $(25 \mathrm{~m} \times 20 \mathrm{~m})$ or $2,500 \mathrm{~m}^{2}(50 \mathrm{~m} \times 50 \mathrm{~m})$, selected on the basis of topographic features and current status of mangroves, were surveyed in November 2015 (Figure 1.). In each plot, survey work was conducted: statistics of the number of trees, measurement of $\mathrm{DBH}$ and $\mathrm{H}$ of all trees, species identification, abnormal characteristics of trees (banyan tree, buttress tree, diameter of buttress, buttress height, etc.) and weighting of fresh biomass of sampled trees.

A total of 31 trees, representative for key plots, are sampled for laboratory analysis. However, in situ identification of sampled trees is carried out and precise measurements are also done for diameter at the stump (position $0.0 \mathrm{~m}$ ), DBH, stem length (from the stump to the highest), height below the branches (from the position $0.0 \mathrm{~m}$ to the main branching point of the tree), trunk length from the base (position $0.0 \mathrm{~m}$ ) to the point of $10 \mathrm{~cm}$ diameter; buttress height and diameter, etc. For the below-ground parts, the coarse roots, greater than $2 \mathrm{~mm}$ in diameter, are dug out for biomass estimation; and the fine roots, less than $2 \mathrm{~mm}$ in diameter, are ignored in this estimation because of the difficulty in separating them from other organic matter in soil. After the in situ measurements, the sampled trees are separated into their parts such as the trunk, branches, leaves, roots and buttress (if present), then weighted for fresh biomass estimation.

Finally, each tree is sampled in stem, branch, leaf and root for laboratory analysis. Stem sample includes 2 - 3 cutting boards or radial cutting boards (if the tree is large) with a mass accounting for $0.2 \%$ of fresh stem. Branch is taken with 4 small cutting 
boards, weighted of $0.5-1.0 \mathrm{~kg}$ in total. All samples are packed in plastic bags and tied tightly to prevent evaporation.

\section{Carbon analysis in tree samples}

Samples taken from roots, stems, branches and leaves of mangroves are dried at $70^{\circ} \mathrm{C}$ for estimating dry mass and moisture content. These dry samples are grinded to the size through $0.2 \mathrm{~mm}$ sieve for analysis. The organic carbon content is determined by Walkley Black method specified in Vietnam Standards (TCVN 9294: 2012).

\section{Mathematical modeling}

Based on the anatomical data of tree samples and imagery data, the mathematical models are used to quantify the relationship between:

- DHB, $\mathrm{H}$ and AGB, i.e. biomass sum of trunk, branches and leave.

- AGB and total biomass, i.e. biomass sum of trunk, branches, leave and root.

- Biomass and accumulated carbon

- AGB and NDVI

The coefficient of determination - $\mathrm{R}^{2}(E q .1)$ and the Standard Error of the regression - SEreg (Eq. 2) are used for measuring the goodness of fit of the models. $\mathrm{F}$ value $(E q .3)$ for F-test is also used to assess whether any of the independent variables in a multiple linear regression are significant.

$$
\begin{gathered}
R^{2}=\frac{\text { SSreg }}{\text { SStot }}=1-\frac{\text { SSres }}{\text { SStot }}=1-\frac{\sum_{i}\left(y_{i}-f_{i}\right)^{2}}{\sum_{i}\left(y_{i}-\bar{y}\right)^{2}} \\
\text { SEreg }=\sqrt{\frac{\sum_{i}\left(y_{i}-f_{i}\right)^{2}}{n-2}} \\
F=\frac{\text { MSreg }}{\text { MSres }}=\frac{\left(\sum_{i}\left(f_{i}-\bar{y}\right)^{2}\right) /(p-1)}{\left(\sum_{i}\left(y_{i}-f_{i}\right)^{2}\right) /(n-p)}
\end{gathered}
$$

where, SSreg is regression sum of squares; SSres is residual sum of squares; SStot is total sum of squares; $y_{i}$ is the measured value; $\bar{y}$ is the mean of $y_{i} ; f_{i}$ is mathematically calculated value; $n$ is number of observations; $p$ is number of regression parameters.

The coefficient of determination $\left(\mathrm{R}^{2}\right)$ ranges from 0 to 1 . In general, the higher the $\mathrm{R}^{2}$, the better the model fits your data and the model could be acceptable if $\mathrm{R}^{2} \geq 0.5$.

The standard error of the regression could be used to obtain a rough estimate of the $95 \%$ prediction interval. About $95 \%$ of the data points are within a range that extends from \pm 2 .SEreg from the fitted line.

In F-test with a significance level $\alpha$, in these cases $\alpha=0.05$, models are accepted if F-value > F-significance and P-value is less than 0.05.

The Microsoft Excel with ANOVA add-in is used for the above-mentioned analyses and mathematical modelling. 


\section{Remote sensing and GIS}

The images should be dated around the moment of field survey for synchronizing the data. Given the weather condition and available data, the image of Sentinel 2A, taken at 10:15:36.027 (local time) on 10 August 2015, the best image close to survey time in November, is chosen for analysis (Figure 1). Its three bands Green (559.8 nm), Red $(664.6 \mathrm{~nm})$ and Near InfraRed - NIR $(832.8 \mathrm{~nm})$ with $10 \mathrm{~m}$ resolutions are used for calculating NDVI and Normalized Difference Water Index (NDWI):

$$
\begin{array}{lc}
\mathrm{NDVI}=(\mathrm{NIR}-\mathrm{Red}) /(\mathrm{NIR}+\mathrm{Red}) & (\text { Rouse } \text { et al. }, 1974) \\
\mathrm{NDWI}=(\text { Green-NIR }) /(\text { Green+NIR }) & (\text { McFeeters, } 1996)
\end{array}
$$

The NDVI value, ranging from -1 to +1 , increases with increased green biomass as a result of increased red reflectance due to greater absorption of incident red light by plant chlorophylls and decreased near-infrared reflectance associated with radiation scattering by the hydrated wall of leaf cells.

NDWI is used to distinguish land and sea by identifying water body with a value greater or equal to threshold of 0.3 for Landsat (McFeeter, 1996, 2013) or 0.1 for Sentinel (Kaplan and Avdan, 2017).

The GIS with ARCGIS software is applied for integration and production of maps presenting spatial variation of data and for extraction of information.

\section{Results and discussion}

\section{Results of plot survey}

Detailed surveys are conducted for all 14 plots with total area of $10600 \mathrm{~m}^{2}$ (Table 1.). 700 trees counted in these plots have mean values of $10.69 \mathrm{~cm}$ and $4.66 \mathrm{~m}$ for DBH and $\mathrm{H}$ respectively. Plot 11, forest of Sonneratia caseolaris in Thuy Truong commune (Thai Thuy district), is the largest mean DBH $(19.19 \mathrm{~cm})$. The smallest mean DBH with value of $5.88 \mathrm{~cm}$ is Plot 7, a recently planted forest of Sonneratia caseolaris - Kandelia obovata - Bruguiera gymnorohiza in Con Den (Tien Hai district). In terms of average height for each plot, Plot 6 is the highest $(9.11 \mathrm{~m})$ and Plot 10 is the lowest $(3.11 \mathrm{~m})$. The highest density is Plot 3 (7600 trees/ha) and the lowest is Plot 12 (100 trees/ha). In general, the older forests have mean DHB and height higher than the overall average because they have long time for growing their dimensions. The high density is statistically related to forests having mean DHB and height lower than the overall average. These forests may be planted on a large scale recently.

\section{Biomass and carbon stored in sampled trees}

Biomass and carbon storage are determined for 31 sample trees with $\mathrm{DBH}$ from $5.41 \mathrm{~cm}$ to $14.01 \mathrm{~cm}$ and height from $1.5 \mathrm{~m}$ to $5.5 \mathrm{~m}$ (Table 2). The analytical results show that the AGB, total biomass and accumulated carbon range $4.11-41.04 \mathrm{~kg}, 4.34$ $43.65 \mathrm{~kg}$ and $2.18-21.83 \mathrm{~kg}$, respectively. The same changing behavior with minimum in Tree 8 and maximum of Tree 31 (Table 2.) shows a close relationship among AGB, total biomass and accumulated carbon. In general, they increase with the growth of tree, i.e. the increase of DHB and height. 
Table 1. Plot survey

\begin{tabular}{|c|c|c|c|c|c|c|c|}
\hline $\begin{array}{c}\text { Plot } \\
\text { number }\end{array}$ & Dominant species & $\begin{array}{c}\text { Length } x \\
\text { Width }(\mathrm{m})\end{array}$ & Area $\left(\mathrm{m}^{2}\right)$ & $\begin{array}{c}\text { Tree } \\
\text { Quantity }\end{array}$ & $\begin{array}{c}\text { Mean of } \\
\text { DHB }(\mathrm{cm})\end{array}$ & $\begin{array}{c}\text { Mean of } \\
\text { Height }(\mathrm{m})\end{array}$ & $\begin{array}{c}\text { Density } \\
\text { (trees/ha) }\end{array}$ \\
\hline 1 & Son. & $25 \times 20$ & 500 & 92 & 10.45 & 5.65 & 1840 \\
\hline 2 & Son., Kan.,Bru. & $25 \times 20$ & 500 & 40 & 11.24 & 4.79 & 800 \\
\hline 3 & Son., Kan.,Bru. & $10 \times 10$ & 100 & 76 & 7.92 & 3.74 & 7600 \\
\hline 4 & Son. & $25 \times 20$ & 500 & 82 & 15.62 & 5.88 & 1640 \\
\hline 5 & Son. & $25 \times 20$ & 500 & 103 & 8.27 & 3.83 & 2060 \\
\hline 6 & Son., Kan.,Bru. & $10 \times 10$ & 100 & 9 & 14.85 & 9.11 & 900 \\
\hline 7 & Son., Kan.,Bru. & $10 \times 10$ & 100 & 67 & 5.88 & 3.90 & 6700 \\
\hline 8 & Kan. & $10 \times 10$ & 100 & 21 & 9.02 & 4.71 & 2100 \\
\hline 9 & Son., Kan.,Bru. & $50 \times 50$ & 2500 & 32 & 11.31 & 3.96 & 128 \\
\hline 10 & Son., Kan.,Bru. & $10 \times 10$ & 100 & 54 & 7.96 & 3.11 & 5400 \\
\hline 11 & Son. & $10 \times 10$ & 100 & 14 & 19.19 & 8.64 & 1400 \\
\hline 12 & Son., Kan.,Bru. & $50 \times 50$ & 2500 & 25 & 16.42 & 5.72 & 100 \\
\hline 13 & Son., Kan.,Bru. & $50 \times 50$ & 2500 & 36 & 14.66 & 5.00 & 144 \\
\hline 14 & Son., Kan.,Bru. & $25 \times 20$ & 500 & 49 & 12.65 & 4.29 & 980 \\
\hline \multicolumn{2}{|r|}{ Overall } & & 10600 & 700 & 10.69 & 4.66 & 660 \\
\hline
\end{tabular}

Note: Son. - Sonneratia caseolaris; Kan. - Kandelia obovata; Bru. - Bruguiera gymnorohiza

Table 2. Dry biomass and carbon storage in sampled trees

\begin{tabular}{|c|c|c|c|c|c|c|c|c|c|}
\hline \multirow{2}{*}{ Tree } & \multicolumn{2}{|c|}{ Parameters } & \multicolumn{6}{|c|}{ Dry biomass (kg) } & \multirow{2}{*}{$\begin{array}{c}\text { Total } \\
\text { carbon } \\
\text { storage }(\mathrm{kg}) \\
\end{array}$} \\
\hline & $\mathrm{DBH}(\mathrm{cm})$ & $\mathrm{H}(\mathrm{m})$ & Trunk & Branch & Leaf & Root & AGB & Total & \\
\hline 1 & 10.98 & 3.9 & 9.5 & 11.03 & 3.74 & 1.89 & 24.27 & 26.16 & 13.09 \\
\hline 2 & 11.14 & 4.2 & 13.82 & 10.8 & 4.5 & 1.85 & 29.12 & 30.97 & 15.49 \\
\hline 3 & 5.57 & 1.5 & 2.93 & 1.89 & 1.08 & 0.95 & 5.9 & 6.85 & 3.44 \\
\hline 4 & 10.98 & 4.45 & 15.26 & 4.32 & 3.15 & 1.4 & 22.73 & 24.13 & 12.07 \\
\hline 5 & 8.59 & 3 & 4.55 & 7.34 & 2.93 & 1.53 & 14.82 & 16.35 & 8.19 \\
\hline 6 & 6.68 & 1.8 & 3.56 & 4.19 & 3.02 & 1.44 & 10.77 & 12.21 & 6.11 \\
\hline 7 & 5.57 & 1.6 & 3.24 & 1.04 & 0.59 & 0.5 & 4.87 & 5.37 & 2.69 \\
\hline 8 & 5.41 & 1.5 & 2.93 & 0.68 & 0.5 & 0.23 & 4.11 & 4.34 & 2.18 \\
\hline 9 & 10.03 & 3.5 & 9 & 10.35 & 3.6 & 1.67 & 22.95 & 24.62 & 12.32 \\
\hline 10 & 11.94 & 4.1 & 13.95 & 11.25 & 4.95 & 2.03 & 30.15 & 32.18 & 16.11 \\
\hline 11 & 7.96 & 2.5 & 5.85 & 3.6 & 1.8 & 0.77 & 11.25 & 12.02 & 6.02 \\
\hline 12 & 11.62 & 4.5 & 15.3 & 4.5 & 3.6 & 1.58 & 23.4 & 24.98 & 12.49 \\
\hline 13 & 8.91 & 2.9 & 4.95 & 7.65 & 3.15 & 1.53 & 15.75 & 17.28 & 8.66 \\
\hline 14 & 7 & 2 & 4.05 & 4.5 & 3.15 & 1.49 & 11.7 & 13.19 & 6.61 \\
\hline 15 & 6.05 & 1.9 & 3.24 & 1.04 & 1.04 & 0.59 & 5.32 & 5.91 & 2.96 \\
\hline 16 & 11.94 & 4.5 & 15.98 & 5.18 & 3.38 & 1.62 & 24.54 & 26.16 & 13.08 \\
\hline 17 & 9.87 & 4 & 9.9 & 10.8 & 3.15 & 1.53 & 23.85 & 25.38 & 12.7 \\
\hline 18 & 12.73 & 4.2 & 15.3 & 11.25 & 4.05 & 2.12 & 30.6 & 32.72 & 16.37 \\
\hline 19 & 6.37 & 2 & 3.15 & 2.25 & 1.35 & 0.54 & 6.75 & 7.29 & 3.66 \\
\hline 20 & 10.19 & 3.7 & 13.95 & 3.15 & 2.25 & 1.08 & 19.35 & 20.43 & 10.23 \\
\hline 21 & 10.5 & 3.4 & 9 & 7.2 & 4.95 & 2.16 & 21.15 & 23.31 & 11.66 \\
\hline 22 & 6.37 & 1.7 & 3.56 & 4.19 & 3.02 & 1.49 & 10.77 & 12.26 & 6.14 \\
\hline 23 & 6.68 & 2.1 & 4.05 & 2.25 & 1.35 & 0.77 & 7.65 & 8.42 & 4.23 \\
\hline 24 & 10.66 & 4.6 & 14.63 & 11.7 & 4.5 & 2.12 & 30.83 & 32.95 & 16.48 \\
\hline 25 & 11.94 & 4.4 & 11.25 & 12.6 & 4.5 & 2.07 & 28.35 & 30.42 & 15.22 \\
\hline 26 & 12.57 & 4.1 & 13.05 & 10.35 & 4.05 & 1.89 & 27.45 & 29.34 & 14.69 \\
\hline 27 & 8.28 & 2.6 & 5.85 & 3.83 & 2.25 & 1.04 & 11.93 & 12.97 & 6.5 \\
\hline 28 & 11.46 & 4.8 & 16.16 & 5.22 & 4.05 & 2.03 & 25.43 & 27.46 & 13.74 \\
\hline 29 & 14.01 & 5.1 & 9.9 & 14.85 & 5.85 & 2.12 & 30.6 & 32.72 & 16.37 \\
\hline 30 & 9.87 & 3.8 & 7.11 & 8.37 & 6.03 & 2.16 & 21.51 & 23.67 & 11.85 \\
\hline 31 & 13.69 & 5.5 & 13.5 & 4.14 & 23.4 & 2.61 & 41.04 & 43.65 & 21.83 \\
\hline
\end{tabular}


Analyzing the correlation of $\mathrm{DBH}$ and $\mathrm{H}$ with AGB, ABG with total biomass, biomass with carbon storage (Table 3.), the following suitable expressions could be chosen:

$$
\begin{gathered}
\text { AGB }=2.110606 * \mathrm{DBH}+3.302734 * \mathrm{H}-11.8674 \\
\text { Biomass }=1.0548 * \mathrm{AGB}+0.4502
\end{gathered}
$$

Carbon $=0.4999 *$ Biomass +0.0127

\begin{tabular}{|c|c|c|c|c|c|c|c|}
\hline & Coefficients & $S E$ & P-value & $\mathbf{R}^{2}$ & SEreg & $F$ & Significance $\boldsymbol{F}$ \\
\hline \multicolumn{8}{|c|}{$\mathrm{ABG} \sim \mathrm{DBH}, \mathrm{H}$} \\
\hline Intercept & -11.8674 & 2.4435 & $4.1041 \mathrm{E}-05$ & \multirow{3}{*}{0.9265} & \multirow{3}{*}{2.7342} & \multirow{3}{*}{176.3669} & \multirow{3}{*}{$1.35 \mathrm{E}-16$} \\
\hline $\mathrm{DBH}$ & 2.1106 & 0.7472 & $8.6232 \mathrm{E}-03$ & & & & \\
\hline $\mathrm{H}$ & 3.3027 & 1.5973 & $4.8028 \mathrm{E}-02$ & & & & \\
\hline \multicolumn{8}{|c|}{ Total biomass $\sim \mathrm{ABG}$} \\
\hline Intercept & 0.4502 & 0.1111 & $3.48346 \mathrm{E}-4$ & & & & \\
\hline $\mathrm{ABG}$ & 1.0548 & 0.0052 & $2.21622 \mathrm{E}-47$ & 0.9993 & 0.2749 & 41898.9073 & $2.22 \mathrm{E}-47$ \\
\hline \multicolumn{8}{|c|}{ Carbon storage $\sim$ Biomass } \\
\hline Intercept & 0.0127 & 0.0023 & 7.1E-06 & & & & \\
\hline Biomass & 0.4999 & 0.0001 & $1.54 \mathrm{E}-87$ & 0.9999 & 0.0057 & 24664592 & $1.54 \mathrm{E}-87$ \\
\hline
\end{tabular}

Table 3. Analysis of $D H B, H, A G B$, biomass and carbon correlations from anatomical data

\section{Correlation between AGB and NDVI}

NDVI is produced from Red and NIR bands of Sentinel image (Eq. 4). This product is integrated with study area (Figure 2.a) and land - sea distribution (Figure 2.b), mapped from NDWI (Eq. 5) with the threshold of 0.1 (Kaplan and Avdan, 2017), to obtain NDVI map for the study area (Figure 2.c). For the study area, NDVI varies from -0.30 to 0.66 , its high value is found in Thuy Truong - Thuy Hai, Thai Thuong and south of Nam Thinh, the low value is commonly around the river mouth. The mean values of surveyed plots (Table 4) extracted from NDVI map are in range of 0.18 (Plot 12) -0.50 (Plot 3 ).
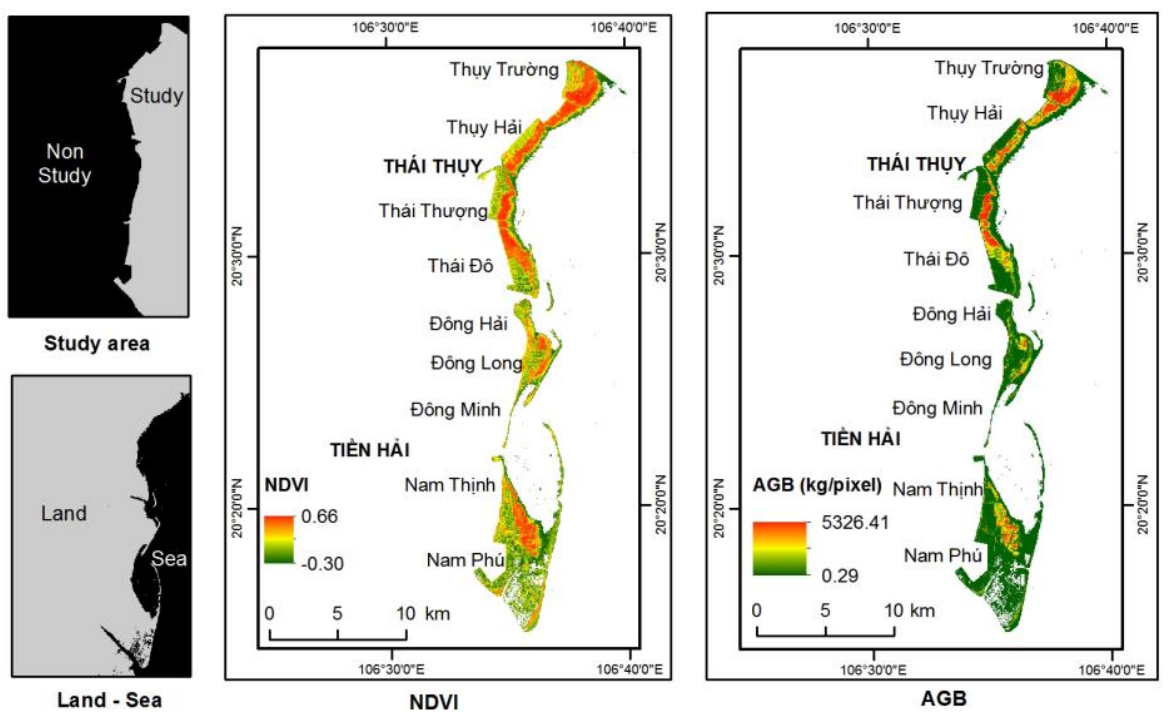

Figure 2. Study area (a), Land - sea distribution (b), NDVI (c) and AGB (d) 


$$
-7508-
$$

Table 4. Estimation of AGB and IDVI for surveyed plots

\begin{tabular}{c|c|c|c|c}
\hline Plot number & AGB $(\mathrm{kg})$ & Area $\left(\mathrm{m}^{2}\right)$ & AGB productivity $\left(\mathrm{kg} / 100 \mathrm{~m}^{2}\right)$ & Mean NDVI \\
\hline 1 & 2666.99 & 500 & 533.40 & 0.42 \\
2 & 1112.42 & 500 & 222.48 & 0.29 \\
3 & 1315.14 & 100 & 1315.14 & 0.50 \\
4 & 3334.79 & 500 & 666.96 & 0.36 \\
5 & 1888.67 & 500 & 377.73 & 0.31 \\
6 & 448.20 & 100 & 448.20 & 0.48 \\
7 & 904.37 & 100 & 904.37 & 0.48 \\
8 & 479.93 & 100 & 479.93 & 0.46 \\
9 & 806.21 & 2500 & 32.25 & 0.31 \\
10 & 826.17 & 100 & 826.17 & 0.43 \\
11 & 803.49 & 100 & 803.49 & 0.46 \\
12 & 1045.78 & 2500 & 41.83 & 0.18 \\
13 & 1285.58 & 2500 & 51.42 & 0.29 \\
14 & 1426.26 & 500 & 285.25 & 0.34 \\
\hline
\end{tabular}

Note: $100 \mathrm{~m}^{2}=1$ pixel $(10 \mathrm{~m} \times 10 \mathrm{~m})$

The AGB of each plot (Table 4.) is estimated from mean values of DBH and $\mathrm{H}$ (Table 1) by the mathematical model expressing their relationship (Eq. 6). AGB values vary from $448 \mathrm{~kg}$ (Plot 6) to $3335 \mathrm{~kg}$ (Plot 4). However, in term of productivity, AGB in an area unit, $100 \mathrm{~m}^{2}$ or 1 pixel for Sentinel image with used bands in this case, the minimum and maximum are $32.25 \mathrm{~kg} / 100 \mathrm{~m}^{2}$ (Plot 9) and $1315.14 \mathrm{~kg} / 100 \mathrm{~m}^{2}$ (Plot 3).

The AGB productivity and NDVI of plots (Table 4.) could be correlated as follow (Figure 3.):

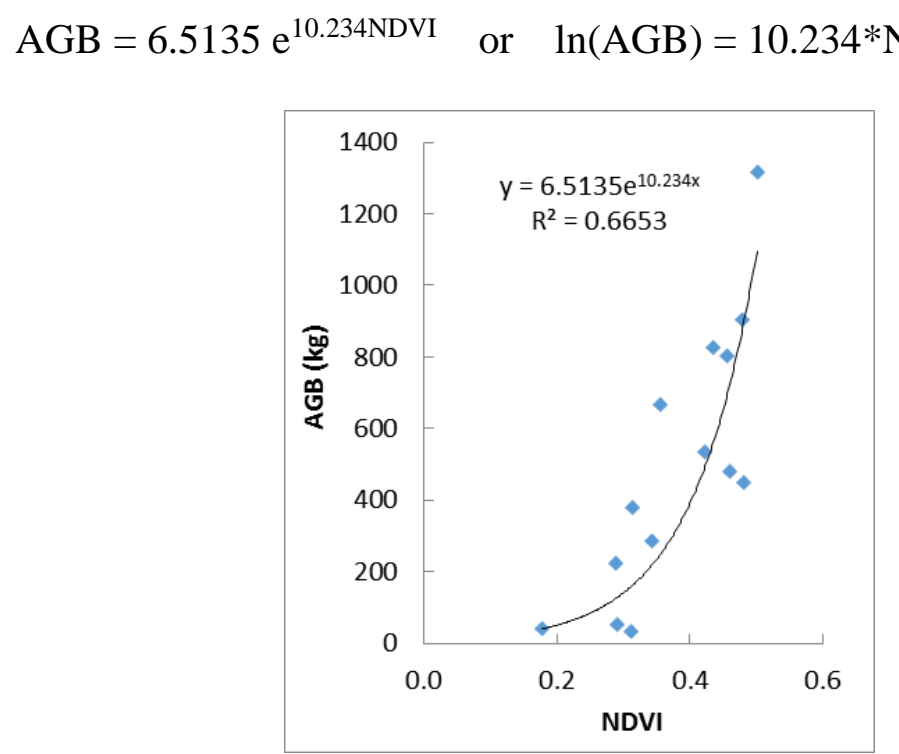

Figure 3. Graph expressing AGB vs. NDVI

Using the coefficient of determination $\mathrm{R}^{2}$ and F-test (Table 5.) show that this expression of AGB - NDVI relation (Eq. 9) is acceptable.

An AGB map is produced from NDVI by the model expressing their relationship (Eq. 6). The AGB in the study area (Figure 2.d) ranges from $0.29 \mathrm{~kg} / \mathrm{pixel}$ to $5326.41 \mathrm{~kg} / \mathrm{pixel}$ with high value in Thuy Truong - Thuy Hai, Thai Thuong and south of Nam Thinh, where also the NDVI is high. 
Table 5. Analysis of $\ln (A G B) \sim N D V I$ correlation

\begin{tabular}{c|c|c|c|c|c|c|c}
\hline & Coefficients & SE & P-value & $\mathbf{R}^{\mathbf{2}}$ & SEreg & $\boldsymbol{F}$ & Significance $\boldsymbol{F}$ \\
\hline Intercept & 1.8739 & 0.8183 & 0.0409 & \multirow{2}{*}{0.6653} & 0.7246 & \multirow{2}{*}{23.8493} & \multirow{2}{*}{0.0004} \\
NDVI & 10.234 & 2.0955 & 0.0004 & & & \\
\hline
\end{tabular}

\section{Biomass and carbon stock in coastal forests}

Biomass as well as carbon stored in forest depend heavily on the species, age and density of trees. In Giao Lac commune (Nam Dinh province), next to the study area, the amount of carbon accumulated in Kandelia obovate forests of 1, 5, 6, 8 and 9 years increases with the ages (Hanh, 2009). In mixed forests of Kandelia obovate and Sonneratia caseolaris with 10,11 and 13 years of Nam Phu commune (Thai Binh province), accumulated carbon in also increases with the age and it in Kandelia obovate $(1.60-2.39 \mathrm{~kg} / \mathrm{tree})$ is much lower than in Sonneratia caseolaris (23.22-37.23 kg/tree); however, due to the tree density, carbon productivity in Kandelia obovate (49.31-124.56 t/ha) is higher than in Sonneratia caseolaris (12.51 - $32.74 \mathrm{t} / \mathrm{ha}$ ) (Hanh, 2015).

For the study area, biomass is estimated from AGB (Eq. 7) and then carbon storage is from biomass (Eq. 8). Biomass and carbon storage (Figure 4.) have high value in the region of Thuy Truong - Thu Hai, Thai Thuong - Thai Do, Nam Hung, where mangrove is planted for long time, and low value around the river mouth, the newly formed land with recently planted mangrove. Biomass extracted from its map ranges from $76 \mathrm{~kg} / \mathrm{ha}$ to $561875 \mathrm{~kg} / \mathrm{ha}$ with an average of $38796 \mathrm{~kg} / \mathrm{ha}$. Carbon storage varies from $39 \mathrm{~kg} / \mathrm{ha}$ to $280882 \mathrm{~kg} / \mathrm{ha}$ with an average value of $19395 \mathrm{~kg} / \mathrm{ha}$. Overall estimations for whole study area, covering approximately 7527 ha (752690 pixel), are $292,014,265 \mathrm{~kg}$ biomass and 145,987,493 kg carbon.
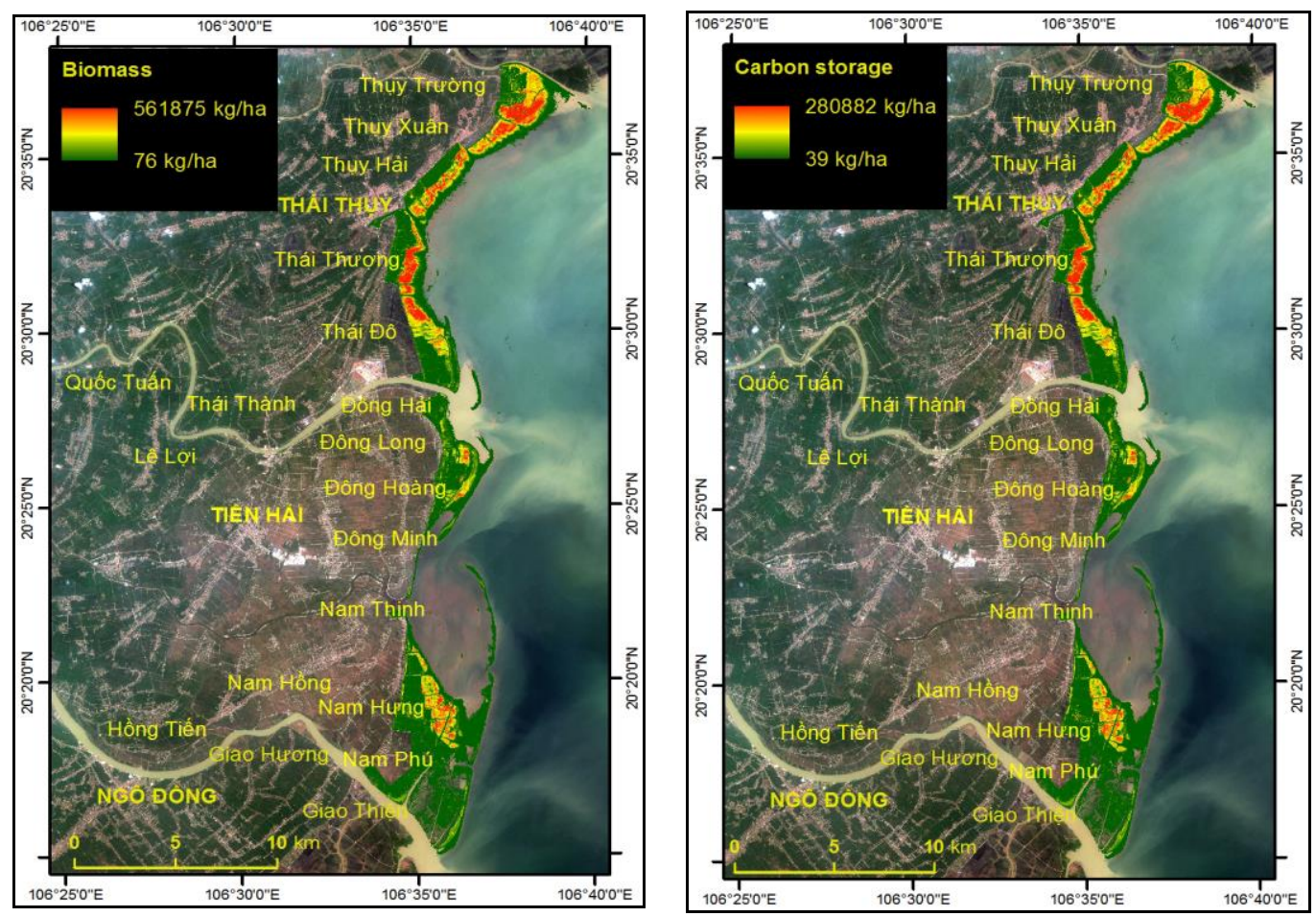

Figure 4. Total biomass (left) and carbon storage (right) 


\section{Forest $\mathrm{CO}_{2}$ valuated through carbon market participation}

The carbon market is seen as the main tool to reduce $\mathrm{CO}_{2}$ emissions, one of the four greenhouse gases. The carbon market activity is supported by four main mechanisms outlined in the Kyoto Protocol, including emissions trading mechanism, CDM, JI and REDD (Höhne et al., 2015). In Vietnam, given the $\mathrm{CO}_{2}$ price from US $\$ 5 / \mathrm{t}$ to US\$10/t, the carbon stored in production forests is valuated from VND $61 \mathrm{million} / \mathrm{ha}$ (restored forest) to VND 119 million/ha (rich forest) for Southern Vietnam, VND 50 - $121 \mathrm{million} / \mathrm{ha}$ for the Central Vietnam and VND 46 - $100 \mathrm{million} / \mathrm{ha}$ for the Northern Vietnam (Vietnamese Academy of Forest Sciences, 2013).

For the study area, as mentioned above, the total carbon in coastal forest is estimated of 145987.49 tons, so the converted $\mathrm{CO}_{2}$, as much as 3.6667 times of carbon, is 535287.47 tons. Based on the lowest $\mathrm{CO}_{2}$ price of US $\$ 11 / \mathrm{t}$ in carbon market price, the total $\mathrm{CO}_{2}$ absorbed in coastal forest of Thai Binh province is valuated of US\$ 5,888,162. This is a significant value for forest managers, especially for local habitants managing the community forests in Tien Hai and Thai Thuy coastal districts of Thai Binh province.

\section{General remarks}

According to TBDARD (2016), coastal forests of Thai Binh province is landward limited by the sea dikes. These dikes are also used as inner limit of study area; the outer is the land - sea boundary, defined by McFeeter (1996) as NDWI $=0.3$ (Figure 2.b). The study area covers 7527 ha, but the statistics of TBDARD (2016) gave a smaller number, 3,899.1 ha of coastal forest for Thai Binh, in which 3,709.1 ha (95\%) is mangroves. This difference is probably due to the study area defined by NDWI takes into account of forests and non-forested area, i.e. lands for residential, garden, crops, public work or other purposes and newly accreted land while the data of TBDARD is only administratively managed forests. Furthermore, the superficies of study area is influenced by imaging time related to tide and weather condition, spatial resolution of image and delineation of outer limit by NDWI. In the case of Fresno city (California, USA), using NDWI to detect swimming pools for Mosquito Abatement has overall classification accuracy of $91.2 \%$ and an overall Kappa coefficient of 0.806 (McFeeters, 2013).

All the mathematical models are assessed by coefficient of determination $\mathrm{R}^{2}(E q .1)$, Standard error of the regression (Eq. 2) and F-test with significance level $\alpha=0.05$ from $\mathrm{F}$ value (Eq.3). The F-test and high $\mathrm{R}^{2}$ show all the chosen mathematical models expressing relationships among DBH, H, AGB, NDVI, biomass and carbon storage, (Eq. 6), (Eq. 7), (Eq. 8) and (Eq. 9), are acceptable. There are close correlations between AGB and DBH and $\mathrm{H}(E q .6)$, biomass and AGB (Eq. 7) and carbon and biomass (Eq. 8 ), expressed by $\mathrm{R}^{2}>0.9$. Lower correlation between NDVI and AGB, $\mathrm{R}^{2}=0.67$, may be due to different time between Sentinel data (Aug 2015) and plot survey (Nov 2015) and also due to few number of sample plots (14 plots).

The study area includes not only mangroves, but also other vegetation in small percentage such as forests of Casuarina equiselifolia and trees planted in gardens, residential and public areas. 


\section{Conclusion}

The coastal forests of Thai Binh province are largely made up of mangroves with dominant species of Sonneratia caseolaris, Kandelia obovate, Bruguiera gymnorohiza and Aegiceras corniculatum, planted for a long time up to now. On an area of $10,600 \mathrm{~m}^{2}$ of 14 plots, there are 700 trees with a mean DBH of $10.69 \mathrm{~cm}$ mean height of $4.66 \mathrm{~m}$. Forests with DBH larger than overall average often have the height above overall average due to longtime plantation. Dense forests are often associated with small trees, recently planted on a large scale.

There are close relationships among DHB, H, AGB, total biomass and accumulated carbon. The AGB, total biomass and accumulated carbon change in the same behavior and they increase with the growth of tree, i.e. the increase of DHB and height.

The relationship between AGB and NDVI could be presented in acceptably exponential model. They have higher value Thuy Truong - Thuy Hai, Thai Thuong and south of Nam Thinh and lower value around the river mouths. Biomass and carbon stock do the same with the average productivities of $38.8 \mathrm{t} / \mathrm{ha}$ and $19.4 \mathrm{t} / \mathrm{ha}$ respectively. Overall estimations for whole study area covering approximately 7527 ha are 292 kilotons biomass and 146 kilotons carbon, worth about US\$ 5.9 million. Most of this value is contributed by mangrove, showing its role not only in coastal protection from erosion but also in economic interest of local community.

The forest biomass and carbon stock could be evaluated from satellite data in combination with plot surveys. In future study, the more accurate assessment requires the synchronous data of both imageries and field survey as well as the adequate plots covering all vegetation's types.

\section{REFERENCES}

[1] Anh, L. T. (2016): Studying ecological functional zoning as a basis for socio-economic sustainable development and proactively adapting to climate change in Thai Binh province. - Project coded VAST.NĐP.02/15-16. Vietnam Academy of Science and Technology. (in Vietnamese).

[2] Baloloy, A. B., Blanco, A. C., Candido, C. G., Argamosa, R. J. L., Dumalag, J. B. L. C., Dimapilis, L. L. C., Paringit, E. C. (2018): Estimation of mangrove forest aboveground biomass using multispectral bands, vegetation indices and biophysical variables derived from optical satellite imageries: RapidEye, PlanetScope and Sentinel-2. - ISPRS Annals of the Photogrammetry, Remote Sensing and Spatial Information Sciences, Volume IV-3, 2018. ISPRS TC III Mid-term Symposium "Developments, Technologies and Applications in Remote Sensing", 7-10 May, Beijing, China.

[3] Bao, H., Poudel, K. P., Kralicek, K., Nguyen, D. H., Phung, V. K., Hailemariam, T. (2016): Allometric Equations for Estimating Tree, Aboveground Biomass in Tropical Dipterocarp Forests of Vietnam. - Forests 7: 180. doi:10.3390/f7080180.

[4] Basuki, T. M., VanLake, P. E., Skidmore, A. K., Hussin, Y. A. (2009): Allometric equations for estimating the above-ground biomass in the tropical lowland Dipterocarp forests. - For. Ecol. Manag. 257: 1684-1694.

[5] Botkin, D. B., Woodwell, G. M., Tempel, N. (1970): Forest Productivity Estimated from Carbon Dioxide Uptake. - Ecology 51(6): 1057-1060.

[6] Brack, D. (2019): Forests and climate change. - In: the UN Forum on Forests Secretariat commissioned three background analytical studies on the contribution of forests to the achievement of the Sustainable Development Goals. 
[7] Chave, J., Réjou-Mechain, M., Burquez, A., Chidumayo, E., Colgan, M. S., Delitti, W. B. C., Duque, A., Eid, T., Fearnside, P. M., Goodman, R. C., Henry, M., Martínez-Yrízar, A., Mugasha, W. A., Muller-Landau, H. C., Mencuccini, M., Nelson, B. W., Ngomanda, A., Nogueira, E. M., Ortiz-Malavassi, E., Pélissier, R., Ploton, P., Ryan, C. M., Saldarriaga, J. G., Vieilledent, G. (2014): Improved allometric models to estimate the above ground biomass of tropical trees. - Glob. Change Biol. 20: 3177-3190.

[8] Clough, B. F., Scott, K. (1989): Allometric relationships for estimating above-ground biomass in six mangrove species. - For. Ecol. Manag. 27: 117-127.

[9] Comley, B. W. T., McGuinness, K. A. (2005): Above- and below-ground biomass, and allometry of four common northern Australian mangroves. - Australian Journal of Botany 53: 431-436.

[10] Cuc, N. T. K., Tan, D. V. (2004): Studying mangrove plants in Thuy Truong commune, Thai Thuy district, Thai Binh province. - In: Phan Nguyen Hong (ed.) Coastal mangrove ecosystem of the Red River Delta: Biodiversity, ecology, socio-economic - management education. Agriculture Publ., Hanoi. (in Vietnamese).

[11] FAO (2010): Global forest resources assessment. - Rome, 56 p.

[12] Federici, S., Lee, D., Herold, M. (2018): Forest mitigation: A permanent contribution to the Paris Agreement. - Climate and land use alliance.

[13] Grier, C. C., Lee, K. M., Nadkarni, N. M., Klock, G. O., Edgenon, P. J. (1989): Productivity of forests of the United States and its relation to soil and site factors and management practices: a review. - Gen. Tech. Rep. PNW-GTR-222. Portland, OR: U.S. Department of Agriculture, Forest Service, Pacific Northwest Research Station, $51 \mathrm{p}$.

[14] Hai, V. D., Trieu, D. T., Tiep, N. H., Bich, N. V., Duong, D. T. (2009): Biomass productivity and carbon accumulation of some major planted forests in Vietnam. Agr. Publ., Hanoi. (in Vietnamese).

[15] Hanh, N. T. H. (2009): Studying carbon accumulation of Kandelia obvata Sheue, Liu \& Yong planted in Giao Thuy district, Nam Dinh province. - Doctoral thesis in Ecology, Hanoi National Univ. Edu, 142 p. (in Vietnamese).

[16] Hanh, N. T. H. (2015): Quantitative study on mangrove mixed of two species in Nam Phu commune, Tien Hai district, Thai Binh province. - Jour. Biol. 37(1): 39-45. doi: 10.15625/0866-7160/v37n1.6134. (in Vietnamese).

[17] Hirata, Y., Furuya, N., Saito, H., Pak, C., Leng, C., Sokh, H., Ma, V., Kajisa, T., Ota, T., Mizoue, N. (2018): Object-Based Mapping of Aboveground Biomass in Tropical Forests Using LiDAR and Very-High-Spatial-Resolution Satellite Data. - Remote Sens. 10: 438. doi:10.3390/rs 10030438 .

[18] Höhne, N., Warnecke, C., Day, T., Röser, F. (2015): Carbon market mechanisms - Role in future international cooperation on climate change. - New climate institute, Cologne, Gemany, $32 \mathrm{p}$.

[19] Hunter, M. O., Keller, M., Victoria, D., Morton, D. C. (2013): Tree height and tropical forest biomass estimation. - Biogeosciences 10: 8385-8399. doi:10.5194/bg-10-83852013.

[20] Jeyanny, V., Balasumdram, S. K., Husni, M. H. A. (2011): Geo-spatial technologies for carbon sequestration monitoring and management. - American Journal of Environmental Sciences 7(5): 456-461.

[21] Kaplan, G., Avdan, U. (2017): Object-based water body extraction model using Sentinel2 satellite imagery. - European Journal of Remote Sens. 50(1): 137-143.

[22] Kebede, B., Soromessa, T. (2018): Allometric equations for above ground biomass estimation of Olea europaea L. subsp. cuspidata in Mana Angetu Forest. - Ecosystem Health and Sustainability 4(1): 1-12. doi: 10.1080/20964129.2018.1433951.

[23] Lung, N. N., Van, N. T. (2004): Trial monetary valuation of planted forests in a clean development mechanism. - Jour. Agr. \& Rural development 12.

[24] Luong, V. N., Tu, T. T., Khoi, A. L., Hong, X. T., Hoan, T. N., Thuy, T. L. H. (2019): Biomass estimation and mapping of Can Gio Mangrove Biosphere Reserve in South of 
Viet Nam using ALOS-2 PALSAR-2 data. - Applied Ecology and Environmental Research 17(1): 15-31.

[25] McFeeters, S. K. (1996): The use of the Normalized Difference Water Index (NDWI) in the delineation of open water features. - Int. J. Remote Sens. 17: 1425-1432.

[26] McFeeters, S. K. (2013): Using the Normalized Difference Water Index (NDWI) within a Geographic Information System to Detect Swimming Pools for Mosquito Abatement: A Practical Approach. - Remote Sens. 5: 3544-3561. doi:10.3390/rs5073544.

[27] Myeong, S., Nowak, D. J., Duggin, M. J. (2006): A temporal analysis of urban forest carbon storage using remote sensing. - Remote Sensing of Environment 101(2): 277-282.

[28] Nam, V. N. (2009): Study on biomass of Ceriops decandra and Lumnitzera racemosa Willd in Can Gio mangrove biosphere reserve. - Summary report of provincial science and technology project, Hochiminh City. (in Vietnamese).

[29] Ostadhashemi, R., Shahraji, T. R., Roehle, H., Limaei, S. M. (2014): Estimation of biomass and carbon storage of tree plantations in northern Iran. - J. Forest Sci. 60(9): 363-371.

[30] Patenaude, G., Hill, R. A., Milne, R., Gaveau, D. L. A., Briggs, B. B. J., Dawson, T. P. (2004): Quantifying forest above ground carbon content using LiDAR remote sensing. Remote Sensing of Environment 93: 368-380. doi: 10.1016/j.rse.2004.07.016.

[31] Pham, T. D., Yoshino, K. (2017): Aboveground biomass estimation of mangrove species using alos-2 palsar imagery in Hai Phong city, Vietnam. - J. Appl. Remote Sens. 11: 026010.

[32] Pham, T. D., Yokoya, N., Dieu, T. B., Yoshino, K., Friess, D. A. (2019): Remote Sensing Approaches for Monitoring Mangrove Species, Structure, and Biomass: Opportunities and Challenges. - Remote Sens. 11: 230. doi:10.3390/rs11020230.

[33] Phuc, L. H. (1996): Evaluating growth and productivity of forest planting Pinus keysiya Royle ex Gordon in Da Lat, Lam Dong. - Doctoral thesis in agricultural science. Vietnamese Academy of forest sciences.

[34] Phuong, V. T. (2006): Studying carbon stock in vegetation - the basis for determining carbon baseline in forestation / reforestation project under the clean development mechanism in Vietnam. - Jour. Agr. \& Rural Development 8: 81-84. (in Vietnamese).

[35] Punalekar, S. M., Verhoef, A., Quaife, T. L., Humphries, D., Bermingham, L., Reynolds, C. K. (2018): Application of Sentinel-2A data for pasture biomass monitoring using a physically based radiative transfer model. - Remote Sensing of Environment 218: 207220.

[36] Quang, T. B., Hoa, L. S. (2018): Using Sentinel satellite image to estimate biomass of mangrove forest in Vinh Quang commune, Tien Lang district, Hai Phong city. - Vietnam Journal of Fore. Sci. Tech. 5: 71-79.

[37] Rouse, J. W., Haas, R. W., Schell, J. A., Deering, D. W., Harlan, J. C. (1974): Monitoring the vernal advancement and retrogradation (greenwave effect) of natural vegetation. Greenbelt, MD, USA, NASA/GSFCT, Type 3, Final Report.

[38] Santoro, M., Cartus, O. (2018): Research Pathways of Forest Above-Ground Biomass Estimation Based on SAR Backscatter and Interferometric SAR Observations. - Remote Sens. 10: 608. doi:10.3390/rs10040608.

[39] Tam, D. D. (2013): Some characteristics of mangrove plants in Dong Long - Tien Hai Thai Binh. - Journal of Forestry Science 4: 3009-3017.

[40] Tan, D. T. (2001): Study on forest biomass of Rhizophoza apiculata in two provinces Ca Mau and Bac Lieu (in Vietnamese).

[41] TBDARD (Thai Binh Department of Agriculture and Rural Development) (2016): Report on forest inventory and data source from forest inventory map 2015. (in Vietnamese).

[42] Thai Binh Statistical Office (2016): Statistical yearbook 2015. (in Vietnamese).

[43] Thong, V. V. (1998): Studying biomass of Acacia auriculiformis for forest business. Master thesis. Vietnam Nati. Univ. Forestry. (in Vietnamese). 
[44] Thuy, T. V., Thanh, P. T., Giang, D. H., Duong, P. M., Ha, N. T., Quoc, N. M. (2016): Studying the effects of climate change on some coastal ecosystems in Thai Binh province and coping capacity. - VNU Journal of Science: Natural Science and Technology 32 (1S). (in Vietnamese).

[45] Tin, N. H. Q., Loi, L. T. (2015): Impact of elevation on carbon accumulation capacity of mangrove in of Ong Trang bar, Ngoc Hien district, Ca Mau province. - Journal of Science, Can Tho Univ.

[46] Tri, H. M. (1986): Contributing to study on biomass and productivity of community of Rhizophora apiculata in Ca Mau, Minh Hai. - PhD thesis in Biology, Hanoi Univ. Edu. (in Vietnamese).

[47] Trieu, D. T. (2010): Studying the carbon fixation capacity of planted forest of Pinus massoniana Lamb and Pinus latteri as a basis for valuating forest environment according to the clean development mechanism in Vietnam. - PhD thesis in Agriculture.

[48] Tuan, M. S., Anh, P. H. (2008): Mangrove vegetation in Tien Hai wetland nature reserve, Thai Binh province. - In: Hong, P. N., Cuc, N. T. K., Hien, V. T. (eds.) Mangrove restoration: responding to climate change towards sustainable development. Agr. Pub., Hanoi, 305 p. (in Vietnamese).

[49] Ty, H. X. (2004): Potential of CDM projects in forestry and landuse change (LULUCF). - Workshop on implementation of clean development mechanism (CDM) in the forestry. Project Office of CD4 CDM - Department of International Cooperation, Ministry of Natural Resources and Environment.

[50] UNFCCC (2007): Action taken by the Conference of the Parties at its thirteenth session. Bali, Indonesia, $60 \mathrm{p}$.

[51] Van, T. T. T., Anh, L. T., Thuy, H. L. T., Bien, L. B. (2017): Bioclimate and mangrove development in Thai Binh coastal zone. - VNU Journal of Science: Earth and Environmental Sciences 33(1): 90-99. (in Vietnamese).

[52] Vietnamese Academy of Forest Sciences (2013): Study on forest valuation in Vietnam. (in Vietnamese).

[53] Vu, T. D., Takeuchi, W., Van, N. A. (2014): Carbon stock calculating and forest change assessment toward REDD+ activities for the mangrove forest in Vietnam. - Trans. Jpn. Soc. Aeronaut. Space Sci. Aerosp. Technol. Jpn. 2014, 12, Pn_23-Pn_31.

[54] Watson, R. T., Noble, I. R., Bolin, B., Ravindranath, N. H., Verardo, D. J., Dokken, D. J. (2000): Land use, land-use change, and forestry. - In: Published for the Intergovernmental Panel on Climate Change. Cambridge University Press, 308 p.

[55] Wofsy, S. C., Goulden, M. L., Munger, J. W., Fan, S. M., Bakwin, P. S., Daube, B. C., Bassow, S. L., Bazzaz, F. A. (1993): Net exchange of $\mathrm{CO}_{2}$ in a Mid-latitude forest. Science 260(5112): 1314-1317.

[56] Woodwell, G. (1970): Effects of Pollution on the Structure and Physiology of Ecosystems. - Science 168(3930): 429-433. doi: 10.1126/science.168.3930.429. 